\title{
Effects of Salinity and Irrigation Management on Growth and Nutrient Concentrations in Poinsettia
}

\author{
Martin P.N. Gent ${ }^{\mathbf{1}}$ and Wade H. Elmer \\ Connecticut Agricultural Experiment Station, New Haven, CT 06504
}

Kranti Macherla and Richard J. McAvoy
University of Connecticut, Storrs, CT 06269

Additional index words. biomass growth, ebb and flow, fertilizer, partial-saturation watering, salt tolerance, sodium

\begin{abstract}
Can regulated deficit irrigation in an ebb and flow system alleviate the effects of salinity stress on poinsettia? Two cultivars of poinsettia (Euphorbia pulcherrima Willd ex Klotzsch) were grown under partial- or full-saturation irrigation using a standard fertilizer solution, with or without the addition of $0.5 \mathrm{~g} \cdot \mathrm{L}^{-1} \mathrm{NaCl}$. The volumetric water content of the medium averaged 0.25 and $0.33 \mathrm{~L} \cdot \mathrm{L}{ }^{-1}$ before irrigation, and 0.5 and $0.67 \mathrm{~L} \cdot \mathrm{L}^{-1}$ following irrigation, for partial- or full-saturation regimes, respectively. Plants had lower fresh weight with partial than full saturation. Sodium concentrations in bract, leaf, and stem tissues were higher $(P \leq 0.05)$ in plants exposed to salinity, and these plants accumulated less $K$ in stems and less $P$ in bracts. Eight cultivars were grown in a second study with or without salinity of $1.2 \mathrm{~g} \cdot \mathrm{L}^{-1} \mathrm{NaCl}$ under drip or ebb and flow watering. Cultivar and watering had effects on plant fresh weight, but salinity did not. Of the cultivars tested, 'DaVinci', 'Premium Picasso', and 'Prestige Red' had the highest sodium in bracts under salinity with drip irrigation, whereas 'Snowcap' had the least. 'Ruby Frost' had the most sodium in stems, whereas 'Snowcap' had the least. For all cultivars, added salinity resulted in lower $K$ in leaves and stem. Snowcap was the cultivar with the least sodium in stems and bracts under saline irrigation, with either drip or ebb and flow. Our research demonstrates that regulated deficit irrigation resulting in partial saturation of the growing medium is an effective water management option, when control of plant height and overall crop growth are desirable, and it limits the accumulation of sodium when raw water contains elevated salinity.
\end{abstract}

Availability of high-quality water is becoming a limited resource for both agricultural and public use. When plants are not sufficiently irrigated, they become water stressed, which causes physiological, molecular, and biochemical changes in the plant (Wang et al., 2003). This can adversely affect both yield and quality. Traditional overhead irrigation uses excess water to ensure complete coverage of the entire crop to the point of full saturation of the root medium. Under certain conditions, up to $75 \%$ of the water and fertilizer applied by overhead irrigation may be lost through evaporation, runoff, or leached from potted plants (Yelanich and Beirnbaum, 1994). Drippers can deliver water directly to the top surface of the root medium; however, studies have shown overwatering by $10 \%$ to $30 \%$ is recommended to prevent salinity buildup in the root medium

Received for publication 15 Jan. 2016. Accepted for publication $23 \mathrm{Feb} .2016$.

Joseph Geremia, Phillip Banning, and Paul Barnes of Geremia Greenhouse, Wallingford, CT, contributed the plant material and technical help. Michael Short and Peter Thiel of the Connecticut Agricultural Experiment Station contributed technical help for analysis of samples.

${ }^{1}$ Corresponding author. E-mail: martin.gent@et. gov.
(Mastalerz, 1977). By comparison, subirrigation, and in particular ebb and flow, systems use water more efficiently (Dole et al., 1994; Elliott, 1992; Morvant et al., 2001), and are also more efficient in terms of nutrient (Kent and Reed, 1996; Purvis et al., 2000) and fertilizer use (Strefeler, 1991). The benefits of ebb and flow, as it is currently applied, are that no water is lost to the environment and very little is lost to evaporation. The root medium may take up water to $90 \%$ of effective water-holding capacity after each cycle. Geremia Greenhouse (Wallingford, CT), in collaboration with True Leaf (Petaluma, CA), developed an irrigation system for potted ornamental plants that can complete an ebb and flow cycle in $4 \mathrm{~min}$. This short cycle restricts water uptake and achieves partial saturation of the root medium, which we refer to as partial-saturation ebb and flow watering (PSEFW). Partial-saturation subirrigation is a method of regulated deficit irrigation where the medium does not saturate during each irrigation event. Pots may take in $25 \%$ less water than those under full saturation (Gent and McAvoy, 2011).

The plant response to salinity is multifaceted and involves changes in plant physiology, morphology, and metabolism (Hilal et al., 1998) and results in reduced plant growth (Rhoades, 1993). Salinity changes the water content in plant cells thereby affecting crop physiology (Hasegawa et al., 2000; Sultana et al., 1999). Water uptake by roots is restricted as excess salts accumulate in the root zone, thereby reducing the capacity for water movement to the shoot. These negative effects of salinity are further exacerbated as the amount of water decreases in the root zone (Warrence et al., 2002). Salinity disrupts various physiological processes: it reduces stomatal conductance $\left(g_{\mathrm{S}}\right)$, chlorophyll content, photosynthetic rates, and transpiration, and increases membrane permeability (Yurtseven et al., 2005). Plants exert more energy to extract water from the soil, which in turn reduces energy available for normal growth processes, resulting in smaller and fewer leaves, reduced root length, and shorter stature (Shannon and Grieve, 1999).

Salinity and alkalinity can reduce greenhouse crop production up to $50 \%$ (Roberts, 1991). Salinity affects the uptake of essential plant nutrients and ultimately leads to deficiency of essential ions and an increase in nonessential ions such as sodium (Greenway and Munns, 1980). With the increase in salinity, leaf $\mathrm{Na}$ and $\mathrm{Cl}$ content also increase (Niu et al., 2010), thereby affecting the uptake of nutrients like $\mathrm{K}$ and $\mathrm{Ca}$, and causing a decrease in plant growth. Sodium can also antagonize root uptake of cations such as $\mathrm{K}, \mathrm{Ca}$, and $\mathrm{Mg}$ (Kuehny and Morales, 1998). Chloride may become toxic at concentrations in excess of $140 \mathrm{mg} \cdot \mathrm{L}^{-1}$ in the saline irrigation water, resulting in symptoms such as marginal or tip necrosis (Biernbaum, 1994).

Regulated deficit irrigation may control disease (Hong and Moorman, 2005). Elmer et al. (2012) found that the incidence of pythium root-rot diseases in crops under PSEFW was significantly reduced compared with crops under full saturation. Another benefit from regulated deficit irrigation is control of both biomass and height growth of ornamental plants (Alem et al., 2015; Lee and van Iersel, 2008). Gent and McAvoy (2011) reported that ornamental crops grown under PSEFW develop the compact stature, most desired by the industry, by accumulating less shoot biomass compared with plants grown under full-saturation irrigation. Water management techniques that can reliably control growth without adversely affecting plant quality are advantageous, since plant growth regulators are commonly used to control height growth in ornamental species. Compared with full saturation, the oxygen content is higher in substrate irrigated with partial saturation, an environment more beneficial to the metabolic activity of roots (Nemati et al., 2002).

However, the effectiveness of partialversus full-saturation management on plant growth and quality has not been reported when there is high background salinity in the irrigation water. Therefore, the objective of this research was to characterize the effects of various irrigation management regimes, with or without added salinity, on the growth and tissue nutrient accumulation of poinsettia grown under partialcompared with longer-duration ebb and flow 
watering, and for plants grown under drip irrigation.

\section{Materials and Methods}

Plant material. The poinsettia (E. pulcherrima) cultivars DaVinci, Marble Star, Maren, Peterstar Red, Premium Picasso, Prestige Red, Ruby Frost, and Snowcap were received from Geremia Greenhouse on 16 Sept. 2012 as rooted cuttings in $15-\mathrm{cm}$ plastic pots.

Environment. The experiment at the University of Connecticut (UCONN, Storrs, CT) was conducted in a $7.25 \times 5.75 \mathrm{~m}$ greenhouse compartment, covered with polycarbonate. On 10 Sept. 2012, the greenhouse was heated to $18.3^{\circ} \mathrm{C}$ (day and night) with first-stage cooling during the day set at $21{ }^{\circ} \mathrm{C}$, then on 16 Nov. 2012 , the minimal temperature was set at $16.7^{\circ} \mathrm{C}$. Night interruption lighting was used to delay the start of flower initiation from 18 Sept. 2012 to 15 Oct. 2012.

At the Connecticut Agricultural Experiment Station (CAES) Lockwood Farm (Hamden, $\mathrm{CT}$ ), a $9 \times 18 \mathrm{~m}$ single-truss greenhouse covered with a double layer of polyethylene film covered two separate but similar flooded floors. The temperature was $16^{\circ} \mathrm{C}$ for heating and $25{ }^{\circ} \mathrm{C}$ for ventilation. Daily maximum temperatures varied between 20 and $34{ }^{\circ} \mathrm{C}$. From mid-Sept. to mid-Dec. 2012, mean air temperatures were 23 and $16{ }^{\circ} \mathrm{C}$ for day and night, respectively. Mean irradiance was $8 \mathrm{~mol} \cdot \mathrm{m}^{-2} \cdot \mathrm{d}^{-1}$ photosynthetically active radiation $(P A R)$ in September, falling to $5 \mathrm{~mol} \cdot \mathrm{m}^{-2} \cdot \mathrm{d}^{-1} P A R$ in December.

The root medium was TG1 (Lafaille and Beaver Peat Co., QC, Canada) composed of $83 \%$ peat $(30 \%, 20 \%$, and $40 \%$ coarse, medium, and fine fibers, and $10 \%$ other) and $17 \%$ perlite by volume, supplemented with $7.5 \mathrm{~kg} \cdot \mathrm{m}^{-3}$ limestone and a complete starter fertilizer, with electrical conductivity (EC) of $1.3 \mathrm{dS} \cdot \mathrm{m}^{-1}$ measured in a saturated extract. Dry density was $76 \mathrm{~g} \cdot \mathrm{L}^{-1}$, with a water retention capacity of 10.2-times dry weight. The effective maximum water-holding capacity with subirrigation was $68 \%$ of root medium volume.

Ebb and flow troughs. Troughs were used as independent irrigation units at UCONN to determine water uptake when the duration of the watering was varied to give partial or full saturation. Each trough was $1.07 \times 0.28 \mathrm{~m}$ and held three plants. Each independent trough was irrigated to either partial or full saturation. Full-saturation troughs were watered for $15 \mathrm{~min}$. Partial-saturation troughs were watered for $4 \mathrm{~min}$. A pump supplied irrigation solution to two troughs at a depth of $2 \mathrm{~cm}$. The initial nutrient solution in each reservoir was a 1:1 mix of calcium nitrate and magnesium sulfate, both added at $1.2 \mathrm{~g} \cdot \mathrm{L}^{-1}$. Following the initial application, the standard fertilizer formulation used for the duration of the experiment was Peters Excel (ICL Specialty Fertilizers, Geldermalsen, NL), $21 \mathrm{~N}-$ $5 \mathrm{P}-16.6 \mathrm{~K}$ peat-lite at $1.2 \mathrm{~g} \cdot \mathrm{L}^{-1}$, with or without the addition of $0.5 \mathrm{~g} \cdot \mathrm{L}^{-1} \mathrm{NaCl}$. Each of three replicated blocks contained eight troughs, comprised of the four irrigation $\times$ salinity treatment combinations for each of two cultivars.

Ebb and flow floors. At CAES, flooded floors of $5.5 \times 6.7 \mathrm{~m}$ in area, were constructed of smooth concrete carefully prepared to give a uniform slope in one direction. The difference in elevation from the lowest elevation to the edge of the floor ranged from 1 to $2.5 \mathrm{~cm}$ (a $0.3 \%$ to $0.8 \%$ slope). The floors had a line of dual-purpose ports distributed across the lowest elevation. A high-capacity pump supplied water from a reservoir to these ports through a manifold under the floor. The pump supplied water for $3 \mathrm{~min}$, by which time the depth of water was 4 to $6 \mathrm{~cm}$, and drained the floor at $6 \mathrm{~min}$. The floor was drained to a sump through the same ports. Drainage was by gravity with a drop of $\approx 0.6 \mathrm{~m}$. The content of each sump was pumped through a particulate filter and back to the reservoir for each floor. The initial nutrient solution in each reservoir was a 1:1 mix of calcium nitrate and magnesium sulfate, both added at $0.6 \mathrm{~g} \cdot \mathrm{L}^{-1}$. A nutrient concentrate of Peters Excel at $21 \mathrm{~N}-5 \mathrm{P}-16.6 \mathrm{~K}$ diluted to $1.2 \mathrm{~g} \cdot \mathrm{L}^{-1}$ was used to make up the solution for each reservoir. One reservoir was also supplied with an additional $1.2 \mathrm{~g} \cdot \mathrm{L}^{-1} \mathrm{NaCl}$, while the other was not. For both floors, a watering cycle was initiated when the gravimetric water content was $\approx 0.1 \mathrm{~L} \cdot \mathrm{L}^{-1}$ on either floor.

Some plants were set on upside-down flats in the middle of each floor and watered by drip irrigation. The input to the reservoirs was sent to a valve that directed water to drip tubes. Four plants of each cultivar were watered for $7 \mathrm{~min}$ with drip irrigation. This was $\approx 65 \mathrm{~L}$ for all 40 drip irrigated plants on each floor. Drip irrigated plants on each floor were watered with the same nutrient solution used to resupply the reservoir for that floor, with or without additional $\mathrm{NaCl}$. Because the subirrigation plants got twice the water of the drip irrigated plants (see Results at CAES below), the drip irrigated plants were watered two times more often.

Experiments at UCONN. The cultivars Peterstar Red and Prestige Red were grown at UCONN. Plants were sorted by size, and plants of equal size were used in each of three replicated blocks (Fig. 1). Each individual plant plus pot was weighed before and after each irrigation event and gravimetric water content was calculated. The final harvest was on 28 Dec. 2012. The plant height, canopy diameter, length of the longest lateral stem, and total shoot fresh weight were recorded for each plant. Five of the youngest mature leaves, the first fully mature true bracts, and the penultimate $10 \mathrm{~cm}$ of stem tissue from each treatment group were collected. The tissue was oven dried at $75{ }^{\circ} \mathrm{C}$ for $72 \mathrm{~h}$ and used for mineral analysis. Average internode length was calculated by dividing stem length by the number of nodes. Canopy cross section was measured from two directions to determine the average canopy diameter.

Experiments at CAES. Eight cultivars of Poinsettia were grown at CAES. There was one plot of each cultivar on each floor. They were spread in a $4 \times 5$ array with four plants of each cultivar watered by drip irrigation. The drip irrigated plants were on the center of each floor (Fig. 2). The water uptake from each reservoir was measured after each irrigation cycle. A subsample of four pots per cultivar and floor were labeled and used to determine medium water content gravimetrically, and water uptake over the course of the experiment at CAES. Each pot remained in position throughout the experiment. Two pots were drip irrigated, and another two were subirrigated. Each labeled pot was weighed before and after each watering. Solution samples were collected and a stirred sample of solution was used to measure EC (model 093262), $\mathrm{pH}$ (model 9256BN), nitrate (model 970701), and potassium (model 931901) (Thermo Fisher Scientific, Waltham, MA). The solution samples were diluted 2:1 with $8 \% \mathrm{v} / \mathrm{v} \mathrm{H}_{2} \mathrm{SO}_{4}$ for analysis of a variety of elements by inductively coupled plasma optical emission spectrometry (model Thermo iCAP 6500; Thermo Fisher Scientific, Waltham, MA).

Plants were harvested on 14 Dec. 2012. Three plants per cultivar and treatment were harvested from each floor, and plant height and canopy diameter (cross section in two directions) were recorded. Stems were cut at soil level and shoot fresh weight was recorded. The longest lateral from the main stem was selected and the length to the base of the inflorescence was measured and the number of nodes counted. The first three true bracts and the three youngest fully expanded green leaves

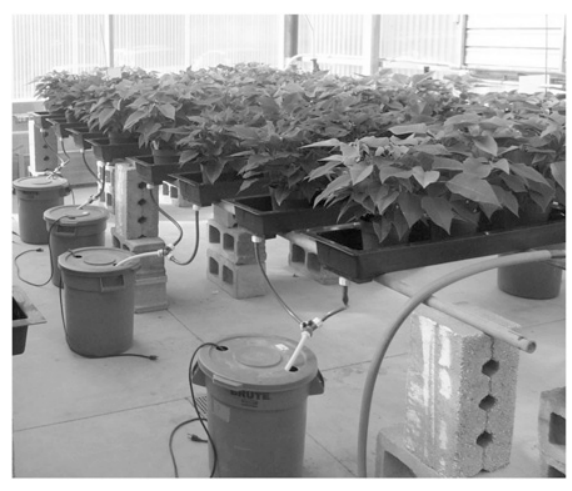

Fig. 1. Experimental layout at the University of Connecticut showing 8 of 24 troughs for watering Poinsettias.

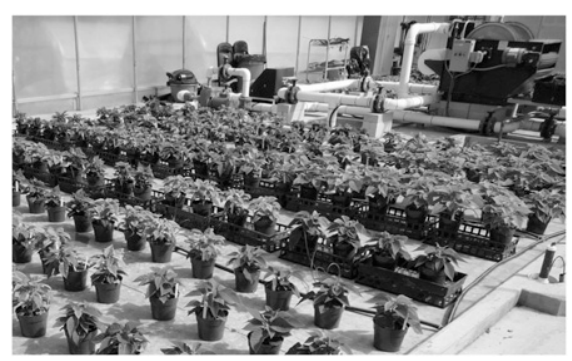

Fig. 2. Experimental layout at the Connecticut Agricultural Experiment Station showing Poinsettia plants watered by ebb and flow and by drip irrigation. 
were selected from each of three stems from each plant. A segment of stem was harvested to $10 \mathrm{~cm}$ from the point of attachment to the main stem. Tissue from the three sampled plants was combined and dried for $3 \mathrm{~d}$ at $75^{\circ} \mathrm{C}$. After drying, plants were weighed. Dried tissue was used for mineral analysis.

Analysis. Three-way analysis of variance (ANOVA) was done in SYSTAT (SPSS Version 10, Richmond, CA). The watering treatment (full or partial saturation), salinity treatment (salinity or no salinity), and two cultivars were fixed effects in ANOVA of the data at UCONN. The blocks were considered as fixed effects in ANOVA of data for the two cultivars. The watering treatment (subirrigation or drip), salinity treatment (salinity or no salinity), and eight cultivars were fixed effects in ANOVA of the data at CAES. Variation between plants was the source of error, which was used to determine least significant difference.

\section{Results}

Water uptake. The gravimetric water content was measured whenever the pots were watered at UCONN. It averaged 0.25 and $0.33 \mathrm{~L} \cdot \mathrm{L}^{-1}$ before irrigation, and 0.50 and $0.67 \mathrm{~L} \cdot \mathrm{L}^{-1}$ following irrigation (Table 1 ), for partial- and full-saturation regimes, respectively. Average water uptake during irrigation was 0.25 and $0.34 \mathrm{~L} \cdot \mathrm{L}^{-1}$, with partial- or full-saturation regimes, respectively. Pots under partial saturation took up only $74 \%$ of the water of pots under full saturation. Gravitational water content was higher for pots treated with salinity, before and after irrigation, compared with control plants, irrespective of the irrigation regime.

During the second watering at CAES on 28 Sept. 2012, EC readings were 1.9 and $1.3 \mathrm{dS} \cdot \mathrm{m}^{-1}$ for reservoirs with and without added salinity. These values rose to 2.7 and $1.6 \mathrm{dS} \cdot \mathrm{m}^{-1}$ by the next to last watering on 26 Nov., due to an increase in salinity in both systems. On all dates, the EC was 2.5 and $1.4 \mathrm{dS} \cdot \mathrm{m}^{-1}$, for drip irrigation with and without added salinity, respectively. On 28 Sept., the reservoirs with and without added salinity had 145 and $23 \mathrm{mg} \cdot \mathrm{L}^{-1}$ sodium, respectively. These values increased to 209 and $31 \mathrm{mg} \cdot \mathrm{L}^{-1}$ on 26 Nov. On 28 Sept., pots weighed 494 and $431 \mathrm{~g}$ before irrigation, and they added 281 and 313 g, due to drip irrigation with and without added salinity, respectively. A second irrigation on 28 Sept. added $140 \mathrm{~g}$ to these drip irrigated pots. The pots weighed 687 and $715 \mathrm{~g}$ before irrigation, and added 389 and $377 \mathrm{~g}$ due to ebb and flow irrigation, with or without added salinity, respectively. By 15 Nov., pots weighed 586 and $527 \mathrm{~g}$ before irrigation, and they added 288 and $322 \mathrm{~g}$, due to drip irrigation, with and without added salinity, respectively. The pots weighed 545 and $527 \mathrm{~g}$ before irrigation, and added 505 and $609 \mathrm{~g}$ due to ebb and flow irrigation, with or without added salinity, respectively. With drip irrigation, pots treated with salinity took up less water than control pots throughout the season, whereas under ebb and flow irrigation, pots treated with salinity took water equal to controls early in the season, but took up less water than control pots irrigation as the season progressed.

Plant growth. At UCONN, 'Peterstar Red' attained greater final plant height, canopy width, lateral branch length, and fresh weight than 'Prestige Red' (Table 1). The fresh

Table 1. Effect of cultivar, salinity at $0.5 \mathrm{~g} \cdot \mathrm{L}^{-1} \mathrm{NaCl}$ versus control, and full versus partial saturation ebb and flow irrigation on the growth of poinsettia at University of Connecticut.

\begin{tabular}{|c|c|c|c|c|c|c|c|c|}
\hline Treatment & $\begin{array}{c}\text { Treatment } \\
\text { levels }\end{array}$ & $\begin{array}{c}\mathrm{Ht} \\
(\mathrm{cm})\end{array}$ & $\begin{array}{l}\text { Width } \\
\text { (cm) }\end{array}$ & $\begin{array}{c}\text { Longest branch } \\
\text { length }(\mathrm{cm})\end{array}$ & $\begin{array}{c}\text { Internode } \\
\text { length }(\mathrm{cm})\end{array}$ & $\begin{array}{c}\text { Plant fresh } \\
\text { wt }(\mathrm{g})\end{array}$ & $\begin{array}{l}\mathrm{GWC}^{\mathrm{z}} \text { before } \\
\text { irrigation }\left(\mathrm{L} \cdot \mathrm{L}^{-1}\right)\end{array}$ & $\begin{array}{c}\text { GWC after } \\
\text { irrigation }\left(\mathrm{L} \cdot \mathrm{L}^{-1}\right)\end{array}$ \\
\hline \multirow[t]{2}{*}{ Cultivar } & Peterstar Red & 38 & 66 & 28 & 1.71 & 286 & 0.30 & 0.60 \\
\hline & Prestige Red & 29 & 57 & 21 & 1.70 & 210 & 0.27 & 0.58 \\
\hline \multirow[t]{2}{*}{ Salinity } & Control & 34 & 63 & 25 & 1.74 & 253 & 0.26 & 0.58 \\
\hline & Salinity & 33 & 60 & 24 & 1.66 & 240 & 0.32 & 0.60 \\
\hline \multirow[t]{2}{*}{ Irrigation } & Full & 35 & 63 & 26 & 1.77 & 261 & 0.33 & 0.67 \\
\hline & Partial & 32 & 60 & 23 & 1.63 & 232 & 0.25 & 0.50 \\
\hline \multicolumn{9}{|l|}{ Significance } \\
\hline Cultivar (C) & & $* * *$ & $* * *$ & $* * *$ & NS & $* * *$ & $* *$ & NS \\
\hline Salinity (S) & & $\mathrm{NS}^{\mathrm{y}}$ & $* *$ & NS & NS & NS & * & $* *$ \\
\hline Irrigation (I) & & $* * *$ & NS & $* * *$ & $* *$ & $* * *$ & $* * *$ & $* * *$ \\
\hline $\mathrm{C} \times \mathrm{S}$ & & NS & NS & NS & $*$ & NS & NS & NS \\
\hline $\mathrm{C} \times \mathrm{I}$ & & NS & NS & NS & NS & NS & NS & NS \\
\hline $\mathrm{S} \times \mathrm{I}$ & & NS & NS & NS & NS & NS & $* *$ & NS \\
\hline $\mathrm{C} \times \mathrm{S} \times \mathrm{I}$ & & NS & NS & NS & NS & NS & NS & NS \\
\hline
\end{tabular}

${ }^{\mathrm{z}} \mathrm{GWC}=($ In situ weight of the pot plus medium - oven dry weight $) /$ total container volume (gram equivalent of water).

${ }^{\mathrm{NSS}}, *, * *, * *$ Nonsignificant or significant at $P \leq 0.05,0.01$, or 0.001 , respectively.

Table 2. Effect of cultivar, salinity at $1.2 \mathrm{~g} \cdot \mathrm{L}^{-1} \mathrm{NaCl}$ versus control, and drip versus ebb and flow irrigation on the growth of poinsettia at the Connecticut Agricultural Experiment Station.

\begin{tabular}{|c|c|c|c|c|c|c|}
\hline Treatment & Treatment levels & $\mathrm{Ht}(\mathrm{cm})$ & Avg width $(\mathrm{cm})$ & Stem length $(\mathrm{cm})$ & Node number & Fresh wt $(\mathrm{g})$ \\
\hline \multirow[t]{8}{*}{ Cultivar } & DaVinci & 27.2 & 49.5 & 23.5 & 14.7 & 196 \\
\hline & Marble Star & 27.8 & 49.3 & 22.3 & 15.7 & 243 \\
\hline & Maren & 28.8 & 52.3 & 23.8 & 15.5 & 268 \\
\hline & Peterstar Red & 32.4 & 56.8 & 26.0 & 16.9 & 278 \\
\hline & Premium Picasso & 20.3 & 35.8 & 15.4 & 13.5 & 205 \\
\hline & Prestige Red & 25.2 & 47.5 & 22.8 & 15.1 & 238 \\
\hline & Ruby Frost & 26.9 & 49.8 & 22.1 & 15.8 & 231 \\
\hline & Snowcap & 32.5 & 56.0 & 28.2 & 18.2 & 279 \\
\hline \multirow[t]{2}{*}{ Salinity } & Control & 27.5 & 50.7 & 23.3 & 16.0 & 244 \\
\hline & Salinity & 27.7 & 48.5 & 23.0 & 15.4 & 240 \\
\hline \multirow[t]{2}{*}{ Irrigation } & Drip & 28.4 & 50.6 & 23.5 & 15.7 & 268 \\
\hline & Ebb and flow & 26.9 & 48.6 & 22.7 & 15.7 & 215 \\
\hline \multicolumn{7}{|l|}{ Significance } \\
\hline Cultivar (C) & & $* * * \mathrm{z}$ & $* * *$ & $* * *$ & $* * *$ & $* * *$ \\
\hline Salinity (S) & & NS & $*$ & NS & $*$ & NS \\
\hline Irrigation (I) & & $* *$ & $* *$ & $*$ & NS & $* * *$ \\
\hline $\mathrm{C} \times \mathrm{S}$ & & NS & NS & NS & NS & NS \\
\hline $\mathrm{C} \times \mathrm{I}$ & & $*$ & $*$ & NS & NS & NS \\
\hline $\mathrm{S} \times \mathrm{I}$ & & NS & NS & NS & NS & $*$ \\
\hline $\mathrm{C} \times \mathrm{S} \times \mathrm{I}$ & & NS & NS & NS & NS & NS \\
\hline
\end{tabular}

${ }_{\mathrm{NSS}}, * * *, * * *$ Nonsignificant or significant at $P \leq 0.05,0.01$, or 0.001 , respectively. 
weight was 76 g greater for 'Peterstar Red' than for 'Prestige Red'. Salinity decreased canopy width by $3 \mathrm{~cm}$ compared with controls. Irrigation treatment affected plant height, fresh weight, longest branch length, and length between internodes (Table 1). Pots given full saturation had plants that were bigger and heavier than those given partial-saturation watering.

Cultivar differences were observed for all of the variables measured at CAES (Table 2). DaVinci and Premium Picasso were the lightest cultivars, and Peterstar Red and Snowcap were the heaviest (Fig. 3). On average, plant fresh weight was greater under drip than ebb and flow irrigation, with differences ranging from a low of $27 \mathrm{~g}$ for 'Premium Picasso' to a high of $70 \mathrm{~g}$ heavier for 'Maren' and 'Snowcap'. Four cultivars were taller by 1.5 to $5.4 \mathrm{~cm}$, whereas three cultivars were shorter by 0.9 to $1.3 \mathrm{~cm}$, under drip compared with ebb and flow (Fig. 4). 'Peterstar Red' was $2.5 \mathrm{~cm}$ taller with drip compared with ebb and flow irrigation. Only canopy width and number of internodes were affected by salinity (Table 2). Control plants were $1.8 \mathrm{~cm}$ wider than those watered with added salinity. Added salinity reduced the number of internodes by 0.6 per stem compared with controls. Comparing the two cultivars Peterstar Red and Prestige Red grown at CAES, Peterstar Red had greater weight, height, and number of internodes than Prestige Red. Control plants of these two cultivars were $1.9 \mathrm{~cm}$ wider, and they had 0.6 more nodes per stem, compared with plants with added salinity. On an average, plants under drip irrigation accumulated $50 \mathrm{~g}$ more fresh weight than those under ebb and flow. In all respects, 'Peterstar Red' was more affected by salinity than 'Prestige Red'.

Elemental composition. At UCONN, bract tissue of 'Prestige Red' had greater concentrations of $\mathrm{K}, \mathrm{P}$, and $\mathrm{Na}$, and lower concentrations of $\mathrm{Ca}$ and $\mathrm{Mg}$, than 'Peterstar Red', and more P in leaf tissue (Table 3). Elevated salinity resulted in decreased $\mathrm{Ca}$ and $\mathrm{Mg}$, and increased $\mathrm{Na}$ in bracts. There were interactions of cultivar with both salinity and irrigation on $\mathrm{Na}$ accumulation in bracts, with higher values for Prestige Red than for Peterstar Red. Under partial saturation, $\mathrm{K}$ concentrations increased in leaves and bracts compared with full saturation. In stems, $\mathrm{Na}$ accumulation was affected by cultivar, salinity treatment, and irrigation regime. 'Prestige Red' had more Na in stem tissue than 'Peterstar Red'. Although added salinity increased $\mathrm{Na}$ accumulation in stems (Table 3), there was less $\mathrm{Na}$ in stems under partial compared with full-saturation irrigation.

At CAES, the concentration of all nutrients in bracts, leaves, and stems varied with cultivar (Table 4). 'Ruby Frost' had the highest amounts of all elements except $\mathrm{Na}$, which was low. The cultivar Prestige Red had higher concentrations of $\mathrm{Na}$ than Peterstar Red. The bracts of these two cultivars differed in all elements except Ca. Salinity increased $\mathrm{Na}$ and decreased $\mathrm{Ca}$ and $\mathrm{Mg}$ in bract tissue. In bracts, $\mathrm{P}$ was higher under drip irrigation, but $\mathrm{Ca}$ and $\mathrm{Mg}$ were higher

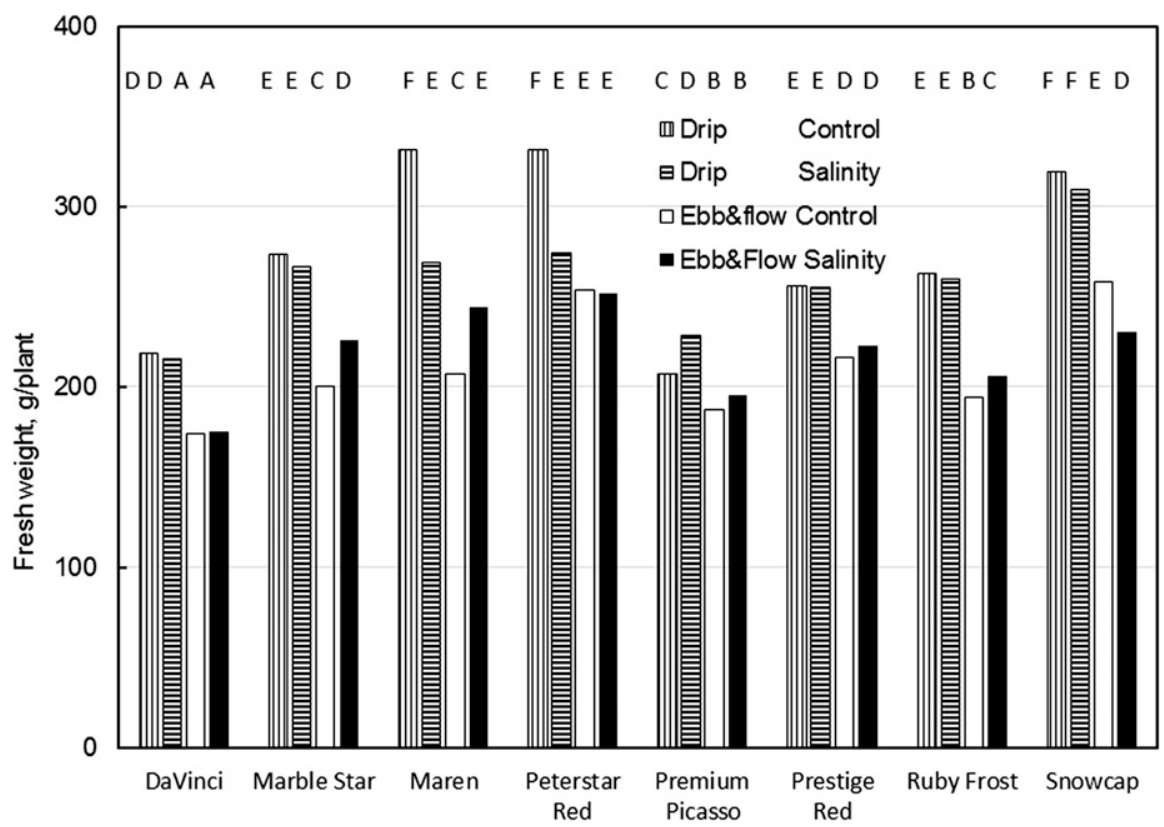

Fig. 3. Effect of salinity at $1.2 \mathrm{~g} \cdot \mathrm{L}^{-1} \mathrm{NaCl}$ versus no salinity, and watering with drip or ebb and flow irrigation, on fresh weight of eight cultivars of poinsettia at the Connecticut Agricultural Experiment Station. Letters indicate significant differences at $P<0.05$ across all cultivars and treatments.

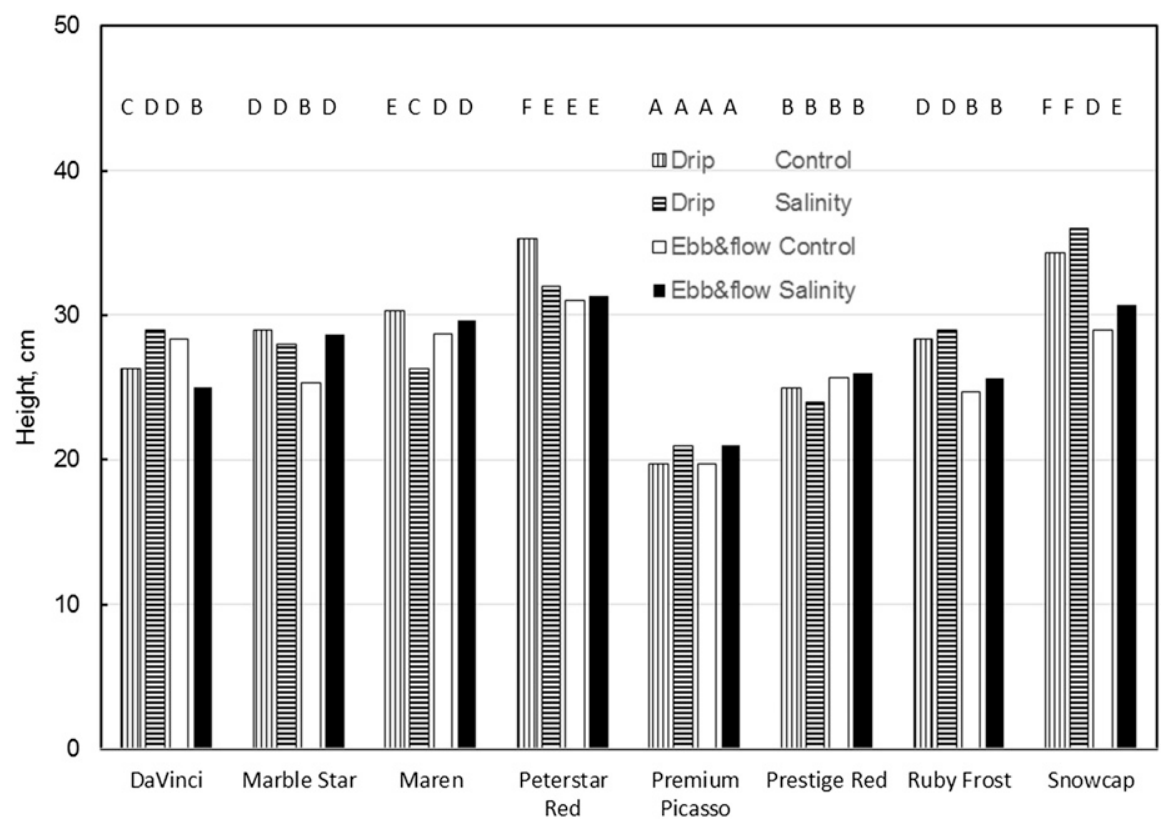

Fig. 4. Effect of salinity at $1.2 \mathrm{~g} \cdot \mathrm{L}^{-1} \mathrm{NaCl}$ versus no salinity, and watering with drip or ebb and flow irrigation, on plant height of eight cultivars of poinsettia at the Connecticut Agricultural Experiment Station. Letters indicate significant differences at $P<0.05$ across all cultivars and treatments.

under ebb and flow. There was an effect of salinity on all elements in bracts, except P. There was an interaction of cultivar and salinity for $\mathrm{Ca}$ and $\mathrm{Na}, P<0.001$, and there was an interaction of cultivar and watering for all elements, $P<0.01$. Elements other than $\mathrm{Na}$ were higher in bracts of controls than in plants with added salinity. The cultivars DaVinci, Premium Picasso, and Prestige Red had the highest $\mathrm{Na}$ concentration with salinity and drip irrigation (Fig. 5). 'Marble Star' and 'Maren' had higher values with salinity and ebb and flow irrigation.
'Snowcap' had lower $\mathrm{Na}$ in bracts than other cultivars.

The irrigation method affected all elements in leaves except $\mathrm{Na}$, and salinity had an effect on all elements, except $\mathrm{K}$ and $\mathrm{Mg}$. There was an interaction of cultivar and salinity for all elements except $\mathrm{Ca}, P<0.01$, and an interaction of salinity and watering for $\mathrm{P}$ and $\mathrm{Mg}, P<0.05$. There was an interaction of cultivar and irrigation for all elements, $P<$ 0.001 for all except $\mathrm{P}$, with $P<0.05$. 'Marble Star' had the highest K, 'DaVinci' and 'Prestige Red' had the highest $\mathrm{P}$ and $\mathrm{Mg}$, and 
Table 3. Effect of cultivar, salinity at $0.5 \mathrm{~g} \cdot \mathrm{L}^{-1} \mathrm{NaCl}$ versus control, and full versus partial-saturation ebb and flow irrigation on elemental composition of bracts, leaves, and stems of poinsettia at University of Connecticut.

\begin{tabular}{|c|c|c|c|c|c|c|}
\hline Treatment & Treatment levels & Potassium $\left(\mathrm{g} \cdot \mathrm{kg}^{-1}\right)$ & Phosphorus $\left(\mathrm{g} \cdot \mathrm{kg}^{-1}\right)$ & Calcium $\left(\mathrm{g} \cdot \mathrm{kg}^{-1}\right)$ & Magnesium $\left(\mathrm{g} \cdot \mathrm{kg}^{-1}\right)$ & Sodium $\left(\mathrm{g} \cdot \mathrm{kg}^{-1}\right)$ \\
\hline \multicolumn{7}{|l|}{$\overline{\text { Bracts }}$} \\
\hline \multirow[t]{2}{*}{ Cultivar } & Peterstar Red & 29.3 & 4.23 & 2.96 & 2.59 & 0.26 \\
\hline & Prestige Red & 36.8 & 5.45 & 2.55 & 2.20 & 0.93 \\
\hline \multirow[t]{2}{*}{ Salinity } & Control & 33.9 & 5.02 & 3.02 & 2.46 & 0.37 \\
\hline & Salinity & 32.8 & 4.76 & 2.45 & 2.29 & 0.87 \\
\hline \multirow[t]{2}{*}{ Irrigation } & Full & 32.8 & 4.82 & 2.71 & 2.41 & 0.73 \\
\hline & Partial & 33.9 & 4.96 & 2.76 & 2.35 & 0.51 \\
\hline \multicolumn{7}{|l|}{ Significance } \\
\hline Cultivar (C) & & $* * * \mathrm{z}$ & $* * *$ & $* * *$ & $* * *$ & $* * *$ \\
\hline Salinity (S) & & NS & $*$ & $* * *$ & $*$ & $* * *$ \\
\hline Irrigation (I) & & NS & NS & NS & NS & $*$ \\
\hline $\mathrm{C} \times \mathrm{S}$ & & NS & NS & NS & NS & $* *$ \\
\hline $\mathrm{C} \times \mathrm{I}$ & & NS & NS & NS & NS & $*$ \\
\hline $\mathrm{S} \times \mathrm{I}$ & & NS & NS & NS & NS & NS \\
\hline $\mathrm{C} \times \mathrm{S} \times \mathrm{I}$ & & NS & NS & NS & NS & $*$ \\
\hline \multicolumn{7}{|l|}{ Leaves } \\
\hline \multirow[t]{2}{*}{ Cultivar } & Peterstar Red & 30.9 & 6.13 & 10.98 & 6.88 & 0.87 \\
\hline & Prestige Red & 30.6 & 7.53 & 11.31 & 7.30 & 0.83 \\
\hline \multirow[t]{2}{*}{ Salinity } & Control & 31.2 & 6.80 & 11.19 & 6.86 & 0.81 \\
\hline & Salinity & 30.3 & 6.98 & 11.13 & 7.36 & 0.89 \\
\hline \multirow[t]{2}{*}{ Irrigation } & Full & 29.6 & 6.80 & 11.38 & 7.33 & 0.85 \\
\hline & Partial & 31.9 & 6.99 & 10.94 & 6.89 & 0.85 \\
\hline \multicolumn{7}{|l|}{ Significance } \\
\hline Cultivar (C) & & NS & $* * *$ & NS & $* *$ & NS \\
\hline Salinity (S) & & NS & NS & NS & NS & $*$ \\
\hline Irrigation (I) & & $* *$ & NS & NS & $* *$ & NS \\
\hline $\mathrm{C} \times \mathrm{S}$ & & NS & NS & NS & NS & $* *$ \\
\hline $\mathrm{C} \times \mathrm{I}$ & & NS & NS & NS & NS & $*$ \\
\hline $\mathrm{S} \times \mathrm{I}$ & & NS & NS & NS & NS & $*$ \\
\hline $\mathrm{C} \times \mathrm{S} \times \mathrm{I}$ & & NS & NS & NS & $*$ & $*$ \\
\hline \multicolumn{7}{|l|}{ Stems } \\
\hline \multirow[t]{2}{*}{ Cultivar } & Peterstar Red & 26.7 & 10.31 & 8.24 & 4.73 & 2.75 \\
\hline & Prestige Red & 29.6 & 10.81 & 9.57 & 4.74 & 5.68 \\
\hline \multirow[t]{2}{*}{ Salinity } & Control & 30.3 & 10.58 & 9.20 & 4.88 & 0.40 \\
\hline & Salinity & 26.3 & 10.58 & 8.73 & 4.58 & 8.28 \\
\hline \multirow[t]{2}{*}{ Irrigation } & Full & 28.2 & 11.09 & 8.92 & 4.65 & 5.77 \\
\hline & Partial & 28.4 & 10.07 & 9.00 & 4.82 & 2.91 \\
\hline \multicolumn{7}{|l|}{ Significance } \\
\hline Cultivar (C) & & $*$ & NS & NS & NS & $* *$ \\
\hline Salinity (S) & & $* *$ & NS & NS & NS & $* * *$ \\
\hline Irrigation (I) & & NS & $*$ & NS & NS & $*$ \\
\hline $\mathrm{C} \times \mathrm{S}$ & & $* *$ & NS & NS & NS & $*$ \\
\hline $\mathrm{C} \times \mathrm{I}$ & & NS & NS & NS & NS & $*$ \\
\hline $\mathrm{S} \times \mathrm{I}$ & & NS & NS & NS & NS & $*$ \\
\hline $\mathrm{C} \times \mathrm{S} \times \mathrm{I}$ & & NS & NS & NS & NS & $*$ \\
\hline
\end{tabular}

$\mathrm{z}_{\mathrm{NS}}, *, * *, * * *$ Nonsignificant or significant at $P \leq 0.05,0.01$, or 0.001 , respectively.

'DaVinci' and 'Premium Picasso' had the highest Na. 'Ruby Frost' had the highest Ca concentrations in poinsettia leaves. Salinity decreased $\mathrm{Ca}$, and leaves had more $\mathrm{K}$ and $\mathrm{P}$, but less $\mathrm{Ca}$, under drip compared with ebb and flow.

Cultivar, irrigation method, and salinity had effects on all elements in the stem. The $\mathrm{Na}$ in stem tissue increased by an average of 5.6-fold with added salinity (Fig. 6). 'Ruby Frost' had the largest increase (8.0-fold) and 'DaVinci' had the smallest (3.6-fold). 'DaVinci' had the highest $\mathrm{Na}$ in stems of controls. 'Snowcap' had the least $\mathrm{Na}$ in stems, under either drip or ebb and flow irrigation. For all elements except $\mathrm{Ca}$, there was an effect of cultivar and salinity, $P<0.001$, and an interaction of watering and salinity, $P<0.05$ for $\mathrm{Mg}, P<0.01$ for $\mathrm{P}$, and $P<0.001$ for $\mathrm{K}$ and $\mathrm{Na}$. There was an interaction of cultivar and watering for all elements, $P<0.001$. 'Marble Star' had the highest amount of K, 'Ruby Frost' had the highest $\mathrm{Ca}$ and $\mathrm{Na}$, and 'Premium Picasso' had the highest Mg. 'Prestige
Red' had more $\mathrm{Ca}$, and 'Peterstar Red' had more $\mathrm{Mg}$ in stems. Salinity and irrigation method had effects on all elements measured for these two cultivars. Salinity reduced tissue accumulation of all elements except $\mathrm{P}$ and $\mathrm{Na}$. When irrigated with salinity, 'Peterstar Red' had 6.7-fold more $\mathrm{Na}$ in stems than with no salinity, and 'Peterstar Red' had 6.5-fold more $\mathrm{Na}$. Irrigation method affected stem tissue accumulation of all elements, with higher levels under drip irrigation for $\mathrm{K}, \mathrm{P}$, and $\mathrm{Na}$, but lower levels for $\mathrm{Ca}$ and $\mathrm{Mg}$ (Table 4).

\section{Discussion}

Poinsettia has been classified as a saltsensitive species (Wallender and Tanji, 2012) with a permissible EC of $2 \mathrm{dS} \cdot \mathrm{m}^{-1}$. Villarino and Mattson (2011) reported a significant decrease in plant fresh weight, height, and width when they tested the effect of salinity at concentrations of $0,20,40,60$, and $80 \mathrm{~mm} \mathrm{NaCl}$ on Euphorbia chamaesyce 'White Manaus'. We used their lowest concentration,
$20.5 \mathrm{~mm} \mathrm{NaCl}$ or $1.2 \mathrm{~g} \cdot \mathrm{L}^{-1} \mathrm{NaCl}$, for the studies at CAES. An even lower concentration was used at UCONN, namely $0.5 \mathrm{~g} \cdot \mathrm{L}^{-1} \mathrm{NaCl}$ or $8.55 \mathrm{~mm} \mathrm{NaCl}$. An added salinity of $0.5 \mathrm{~g} \cdot \mathrm{L}^{-1} \mathrm{NaCl}$ at $\mathrm{UCONN}$ only affected canopy width. By comparison, the changes in poinsettia growth due to salinity at this concentration were relatively moderate compared with the differences observed between cultivars independent of salinity. For example, plant fresh weight was only affected by cultivar and irrigation management, not salinity. Salinity had no effect on plant height, fresh weight, or internode length, suggesting that poinsettia is fairly tolerant to salinity stress. The added salinity at CAES was $1.2 \mathrm{~g} \cdot \mathrm{L}^{-1} \mathrm{NaCl}$, but the overall effects on plant growth were similar to those at UCONN. Only canopy width and number of internodes were affected by salinity at CAES, and drip irrigation compared with ebb and flow affected plant fresh weight, although salinity did not.

Overall, the results herein suggest that irrigation water with a background salinity in 
Table 4. Effect of cultivar, salinity at $1.2 \mathrm{~g} \cdot \mathrm{L}^{-1} \mathrm{NaCl}$ versus control, and drip versus ebb and flow watering on elemental composition of bracts, leaves, and stems of poinsettia at the Connecticut Agricultural Experiment Station.

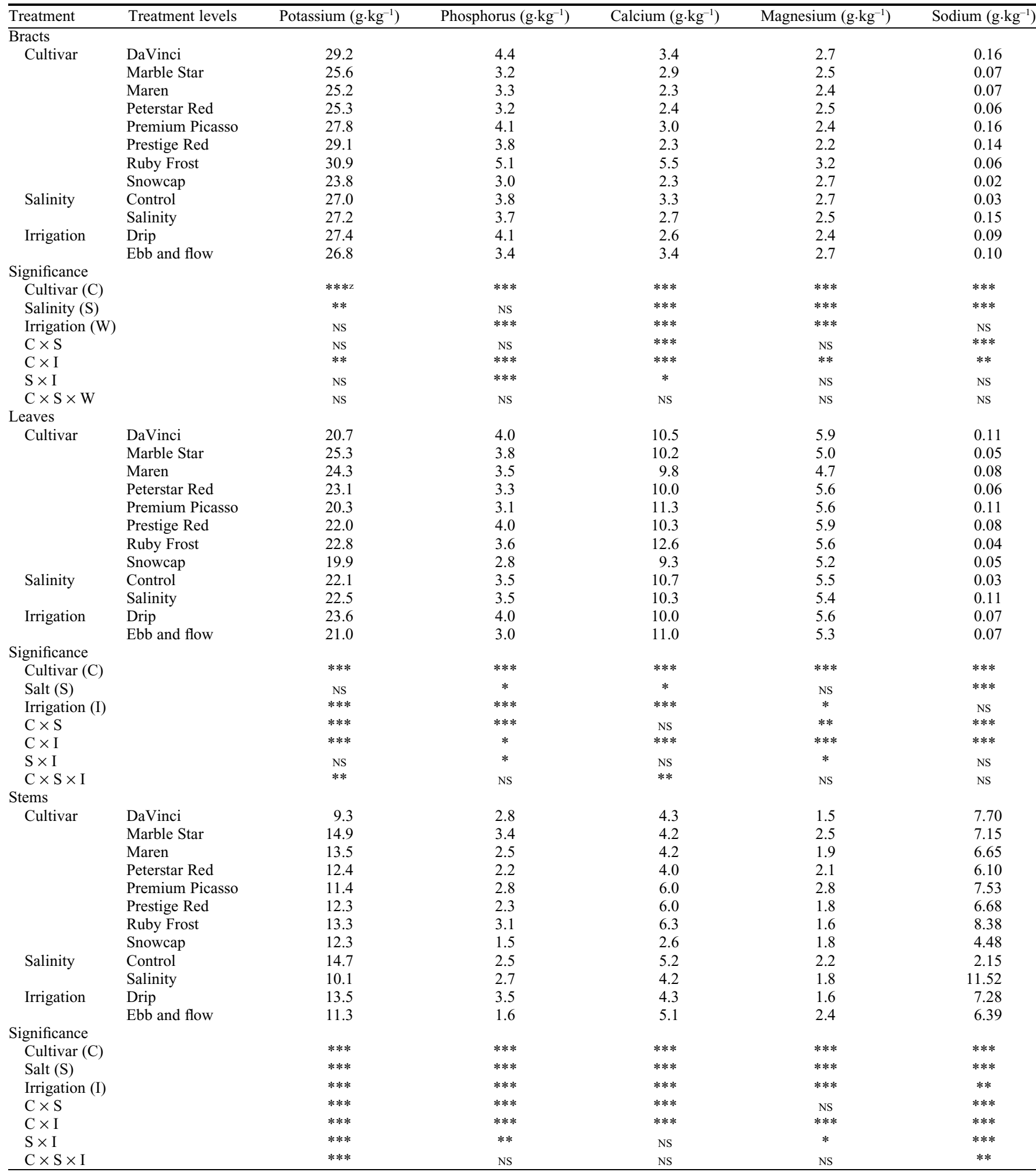

${ }_{\mathrm{NSS}}, *, * * * * *$ Nonsignificant or significant at $P \leq 0.05,0.01$, or 0.001 , respectively.

the range of $0.5-1.2 \mathrm{~g} \cdot \mathrm{L}^{-1}$ does not affect plant quality of poinsettia. Poinsettia plants exposed to salinity accumulated more $\mathrm{Na}$ in stems, a characteristic associated with halophytes (Munns, 1993). This observation suggests that poinsettia may prevent $\mathrm{Na}$ accumulation in leaf tissue by sequestering it in stems. Since $\mathrm{Na}$ has been found to reduce transpiration, chlorophyll content, and photosynthetic rates in leaves (Charbaji and Ayyoubi, 2004; Dhindsa et al., 1981; Lee and van Iersel, 2008; Pasternak, 1987), stem accumulation would serve to reduce these detrimental effects. This was most evident in 'Ruby Frost', which accumulated the highest concentrations of $\mathrm{Na}$ in stems, but the lowest concentrations in leaves and bracts, while accumulation of other cations in bracts and leaves were comparatively high. Snowcap was the cultivar with the least $\mathrm{Na}$ in stems and bracts under salinity, with either drip or ebb and flow irrigation. This cultivar also had the greatest plant height and fresh weight, under drip irrigation. The lack of $\mathrm{Na}$ in all parts of 


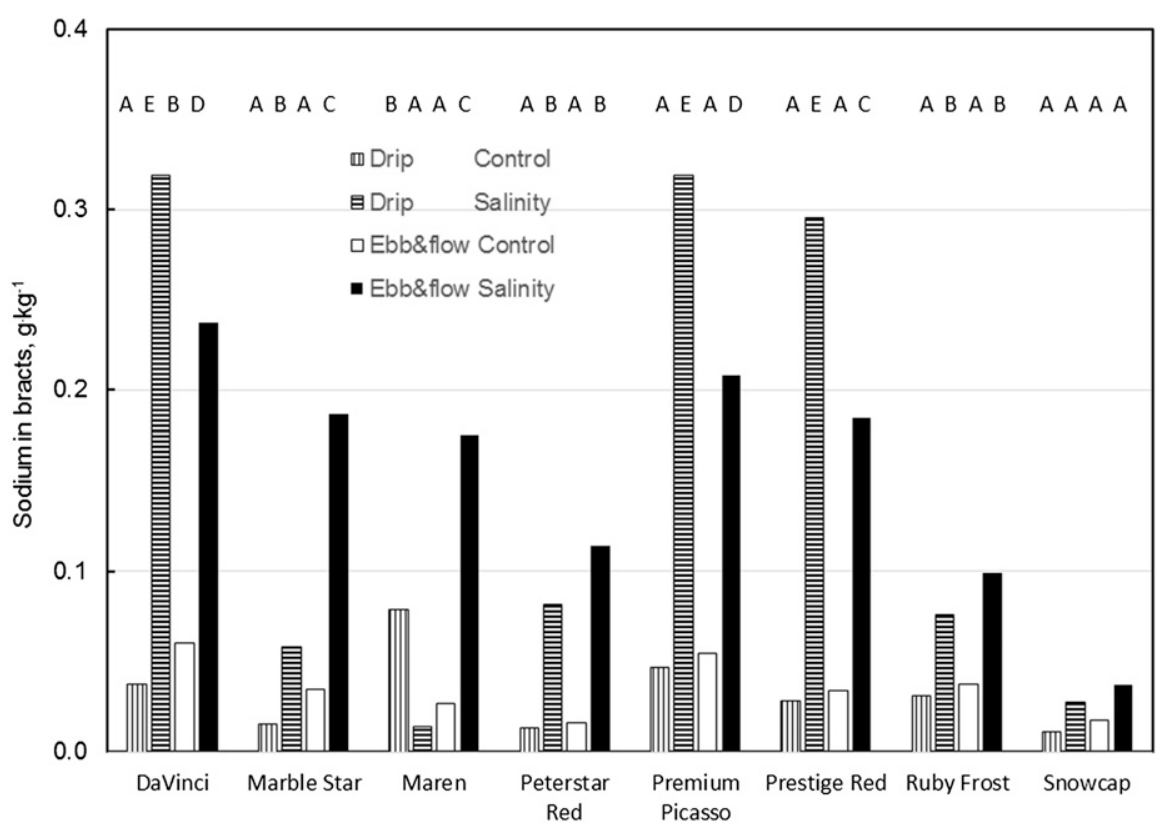

Fig. 5. Effect of salinity at $1.2 \mathrm{~g} \cdot \mathrm{L}^{-1} \mathrm{NaCl}$ versus no salinity, and watering with drip or ebb and flow irrigation, on sodium in bracts of eight cultivars of poinsettia at the Connecticut Agricultural Experiment Station. Letters indicate significant differences at $P<0.05$ across all cultivars and treatments.

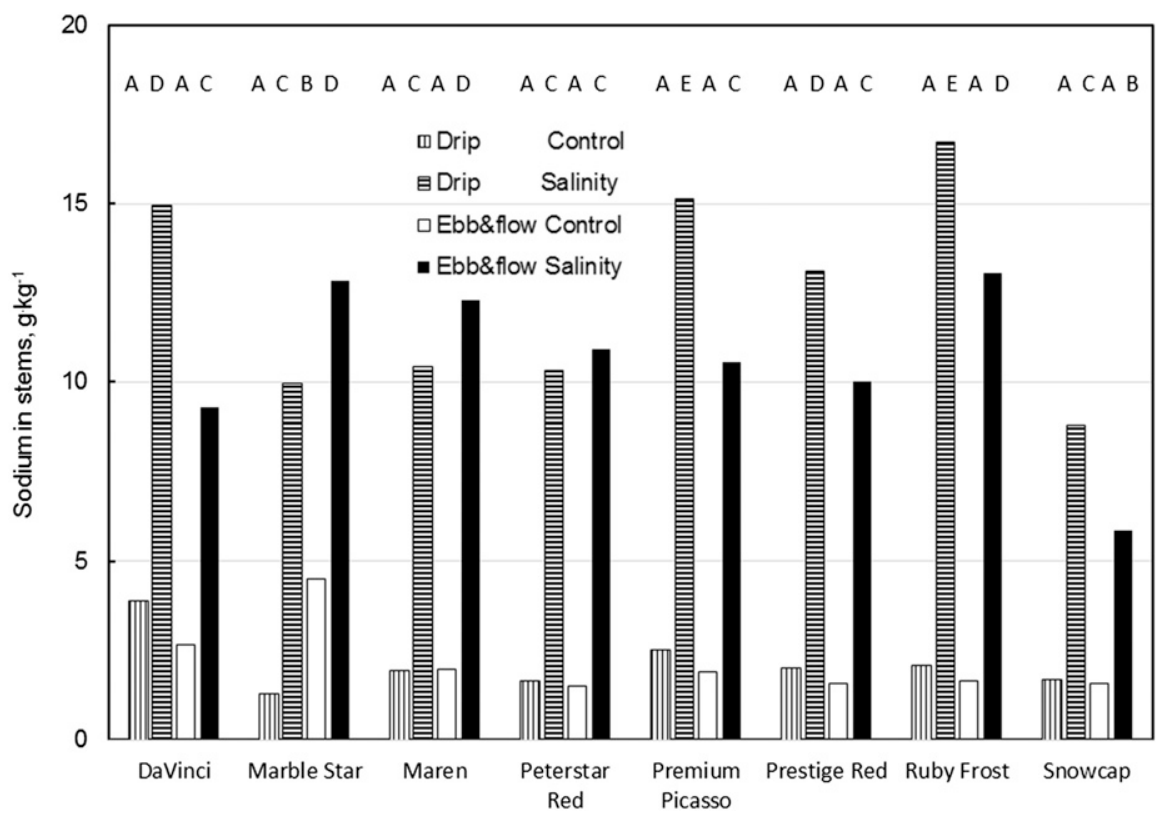

Fig. 6. Effect of salinity at $1.2 \mathrm{~g} \cdot \mathrm{L}^{-1} \mathrm{NaCl}$ versus no salinity, and watering with drip or ebb and flow irrigation, on sodium in stems of eight cultivars of poinsettia at the Connecticut Agricultural Experiment Station. Letters indicate significant differences at $P<0.05$ across all cultivars and treatment.

'Snowcap', and low Na in bracts and leaves of 'Ruby Frost', should be studied to find other cultivars that would thrive under conditions of poor water quality.

At UCONN, Na accumulation in both the root medium and plant tissue was directly related to the total quantity of irrigation solution taken up over time. Similarly at CAES, plants under drip irrigation management received more irrigation solution over time and accumulated more $\mathrm{Na}$ in shoot tissue than height growth in ornamentals is an important crop management concern, water management strategies that control plant growth while limiting tissue accumulation of $\mathrm{Na}$ are advantageous when raw water quality is poor. Our research shows that a background concentration of $\mathrm{NaCl}$ in the range of 0.5 to $1.2 \mathrm{~g} \cdot \mathrm{L}^{-1}$ had only a moderate effect on poinsettia growth, compared with the differences observed between cultivars, or the effects of irrigation management.

The degree of medium saturation at each irrigation event had a more dramatic effect on overall plant size than did salinity, with greater plant height and fresh weight under full than partial-saturation management. This study demonstrates that partial saturation can be used as an effective water management option, when control over overall plant height and crop growth is desirable, and has the added benefit of limiting toxic accumulation of $\mathrm{Na}$ when raw water contains elevated salinity.

\section{Literature Cited}

Alem, P., P.A. Thomas, and M.W. van Iersel. 2015. Controlled water deficit as an alternative to plant growth retardants for regulation of poinsettia stem elongation. HortScience 50:565-569.

Biernbaum, J.A. 1994. Water quality. Tips on growing bedding plants. 3rd ed. The Ohio Florists' Association, Columbus, $\mathrm{OH}$.

Charbaji, T. and Z. Ayyoubi. 2004. Differential growth of some grapevine varieties in Syria in response to salt in vitro. In Vitro Cell. Dev. Biol. 40:221-224.

Dhindsa, R.S., P. Plumb-Dhindsa, and T.A Thorpe. 1981. Leaf senescence: Correlated with increased levels of membrane permeability, lipid peroxidation, and decreased levels of superoxide dismutase and catalase. J. Expt. Bot. 32:93-101.

Dole, J.M., J.C. Cole, and S.L. von Broembsen. 1994. Growth of poinsettias, nutrient leaching, and water use efficiency respond to irrigation methods. HortScience 29:858-864.

Elliott, G.C. 1992. Imbibition of water by rockwool-peat container media amended with hydrophilic gel or wetting agent. J. Amer. Soc. Hort. Sci. 117:757-761.

Elmer, W.H., M.P.N. Gent, and R.J. McAvoy. 2012. Partial saturation under ebb and flow irrigation suppresses Pythium root rot of ornamentals. Crop Prot. 33:29-33.

Gent, M.P.N. and R.J. McAvoy. 2011. Water and nutrient uptake and use efficiency with partial saturation ebb and flow watering. HortScience 46:791-798

Greenway, H. and R. Munns. 1980. Mechanisms of salt tolerance in nonhalophytes. Annu. Rev. Plant Physiol. 31:149-190.

Hasegawa, P., R.A. Bressan, J.K. Zhu, and H.J. Bohnert. 2000. Plant cellular and molecular responses to high salinity. Ann. Rev. Plant Physiol. Plant Mol. Biol. 51:463-499.

Hilal, M., A.M. Zenoff, G. Ponessa, H. Moreno, and E.M. Massa. 1998. Saline stress alters the temporal patterns of xylem differentiation and alternative oxidase expression in developing soybean roots. Plant Physiol. 117:695-701.

Hong, X.C. and G.W. Moorman. 2005. Plant pathogens in irrigation water: Challenges and opportunities. Crit. Rev. Plant Sci. 24:189-208.

Kent, M.W. and D.W. Reed. 1996. Nitrogen nutrition of New Guinea impatiens 'Barbados' and Spathiphyllum 'Petite' in a sub irrigation system. J. Amer. Soc. Hort. Sci. 121:816-819. 
Kuehny, S. and B. Morales. 1998. Effects of salinity and alkalinity on pansy and impatiens in three different growing media. J. Plant Nutr. 21:1011-1023.

Lee, M. and M.W. van Iersel. 2008. Sodium chloride effects on growth, morphology, and physiology of Chrysanthemum (Chrysanthemum $\times$ morifolium). HortScience 43:1888-1891.

Mastalerz, J.W. 1977. How much water to apply? The greenhouse environment, p. 426. Wiley, New York, NY.

Morvant, J.K., J.M. Dole, and J.C. Cole. 2001. Fertilizer source and irrigation system affect geranium growth and nitrogen retention. HortScience 36:1022-1026.

Munns, R. 1993. Physiological processes limiting plant growth in saline soils: Some dogmas and hypotheses. Plant Cell Environ. 16:15-24.

Nemati, M.R., J. Caron, O. Banton, and P. Tardif. 2002. Determining air entry value in peat substrates. J. Soil Sci. Soc. Amer. 66:367-373.

Niu, G., S. Rodriguez, and T. Starman. 2010. Response of bedding plants to saline water irrigation. HortScience 45:628-636.
Pasternak, D. 1987. Salt tolerance and crop production - a comprehensive approach. Annu. Rev. Phytopathol. 25:271-291.

Purvis, P., C. Chong, and G.P. Lumis. 2000. Recirculation of nutrients in container nursery production. Can. J. Plant Sci. 80:39-45.

Rhoades, J.D. 1993. Practices to control salinity in irrigated soil, p. 379-387. In: H. Leith and A. Al-Masoom (eds.). Towards the rational use of high salinity tolerant plants. Vol. 2. Kluwer Academic Publishers, Dordrecht, NL.

Roberts, D.R. 1991. Water woes. Greenhouse Manager 10(2):60-62.

Shannon, M.C. and C.M. Grieve. 1999. Tolerance of vegetable crops to salinity. Sci. Hort. 78:5-38.

Strefeler, M. 1991. A brief overview of various closed irrigation systems and other methods of reducing contaminated runoff from greenhouses. Minnesota Flower Growers Bulletin 40(3).

Sultana, N., T. Ikeda, and R. Itoh. 1999. Effect of $\mathrm{NaCl}$ salinity on photosynthesis and dry matter accumulation in developing rice grains. $\mathrm{J}$. Environ. Exp. Bot. 42:211-220.

Villarino, H. and S. Mattson. 2011. Assessing tolerance to sodium chloride salinity in fourteen floriculture species. HortTechnology 21:539-545.
Wallender, W.W. and K.K. Tanji. 2012. Nature and extent of agricultural salinity and sodicity. In: W.W. Wallender and K.K. Tanji (eds.). Agricultural salinity assessment and management. 2nd ed. American Society of Civil Engineers, Reston, VA.

Wang, W., B. Vinocur, and A. Altman. 2003. Plant response to drought, salinity and extreme temperature: Towards genetic engineering for stress tolerance. Planta 218:1-14.

Warrence, N.J., J.W. Bauder, and K.E. Pearson. 2002. The basics of salinity and sodicity effects on soil physical properties. Department of Land Resources and Environmental Sciences, Montana State University, Bozeman, MT.

Yelanich, M.V. and J.A. Beirnbaum. 1994. Fertilizer concentration and leaching affect nitratenitrogen leaching from potted poinsettia. HortScience 29:874-875.

Yurtseven, E., G.D. Kesmez, and F.A. Unlukara 2005. The effects of water salinity and potassium levels on yield, fruit quality and water consumption of a native central anatolian tomato species (Lycopersicon esculentum). Agr. Water Mgt. 78:128-135. 